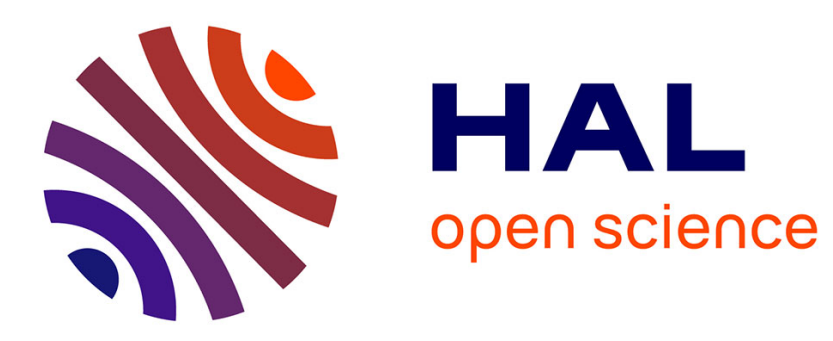

\title{
Upper secondary chemistry students in a pharmacochemistry research community
}

Lisette van Rens, Jacqueline Van Muijlwijk, Jos Beishuizen, Joop van Der

Schee

\section{- To cite this version:}

Lisette van Rens, Jacqueline Van Muijlwijk, Jos Beishuizen, Joop van Der Schee. Upper secondary chemistry students in a pharmacochemistry research community. International Journal of Science Education, 2011, pp.1. 10.1080/09500693.2011.591845 . hal-00721224

\section{HAL Id: hal-00721224 \\ https://hal.science/hal-00721224}

Submitted on 27 Jul 2012

HAL is a multi-disciplinary open access archive for the deposit and dissemination of scientific research documents, whether they are published or not. The documents may come from teaching and research institutions in France or abroad, or from public or private research centers.
L'archive ouverte pluridisciplinaire HAL, est destinée au dépôt et à la diffusion de documents scientifiques de niveau recherche, publiés ou non, émanant des établissements d'enseignement et de recherche français ou étrangers, des laboratoires publics ou privés. 

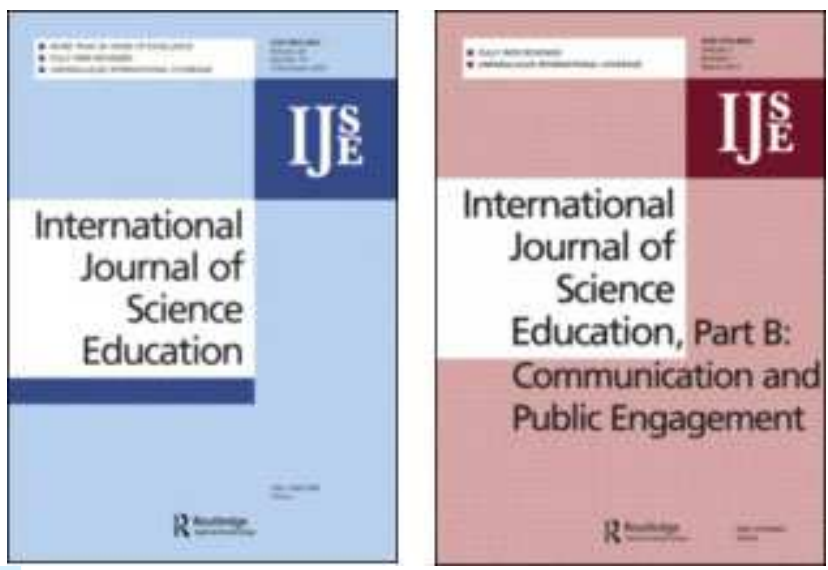

\section{Upper secondary chemistry students in a pharmacochemistry research community}

\begin{tabular}{|r|l|}
\hline Journal: & International Journal of Science Education \\
\hline Manuscript ID: & TSED-2010-0417-A.R2 \\
\hline Manuscript Type: & Research Paper \\
\hline Keywords : & chemistry education, design study, nature of science \\
\hline Keywords (user): & \\
\hline & \\
\end{tabular}

\section{SCHOLARONE Manuscripts}




\section{Upper secondary chemistry students in a pharmacochemistry research community}

This study deals with the participation of ten upper secondary chemistry students, age 16-17, and their chemistry teacher in a pharmacochemistry research community on anti-allergy medicines at University XX. Participation of the students in scientific research raises the question of how to bridge the gap between an upper secondary school inquiry practice and a scientific research practice. To bridge this gap, a design based on six principles derived from an educational model of a community of learners was proposed. The study firstly aimed at revealing whether the proposed principles were necessary according to the students, their teacher and three pharmacochemistry researchers for successful participation of the students in the research community. Secondly, the study examined whether the students' understanding of discipline-specific content knowledge, interest in scientific research and knowledge about the nature of science changed during the course of the study. Data were obtained from questionnaires, interviews and video tapes. The results indicated that according to the teacher all six principles were necessary to bridge the gap, whereas according to the students one principle and according to the pharmacochemistry researchers two principles were necessary but difficult to achieve. Furthermore, all students gained discipline-specific content knowledge. Their interest in scientific research exhibited a positive change and their knowledge about the nature of science increased. The implications for further research and practice are discussed. 


\section{Introduction}

In efforts to implement inquiry based curricula in secondary school there has been a growing interest in studying students and teachers who are involved in authentic research activities (Krajcik, Blumenfeld, Bass, Fredericks, \& Solloway, 1998; Kass, \& Macdonald, 1999; Roth, 1996; xx, 2004; Windschitl, Thomson, \& Braaten, 2008). This way, authenticity is considered as an approach to student learning by inquiry with the activities of researchers as a model for designing the inquiry-learning environment in class (e.g. Barab, \& Hay, 2001). These activities also include the process by which the inquiry results are discussed and accepted in the research community (Driver, Leach, Millar, \& Scott, 1996; Gilbert, 2004; xx, 2010; Wenger, 1998).

However, Helms (1998) concluded that modelling researchers' activities in class is not sufficient enough for upper secondary school students to gain an understanding of the scientific research practice. Helms (ibid.) argues that understanding the scientific research practice can best be achieved by students when they participate in a research laboratory or field setting; the participation model. Participation by secondary school students in a real research community raises the issue of how to bridge the gap between an upper secondary school inquiry practice and a scientific research practice (O’Neill, \& Polman, 2004). In the current article, a study on necessary design principles to bridge this gap and the impact on the understanding of this practice by participating upper secondary chemistry students, age 16-17, is presented.

The study was guided by the following research questions:

(i) which design principles are necessary for a successful participation of upper secondary chemistry students in an authentic research community?

(ii) what changes occur in the students' discipline-specific content knowledge and interest in scientific research as well as in the students' knowledge on scientific investigation and NOS 
by participating in such a designed community? The result of the study may contribute to a research-based design that bridges the gap between an upper secondary school inquiry practice and a scientific research practice in such a way that upper secondary chemistry students who participate in the designed scientific research environment gain knowledge on and interest in scientific research.

\section{Theoretical perspective}

\section{Design principles}

In the traditional view, scientific practices can fit within the methodological model of knowledge production (Pera, 1994; Windschitl, Thomson, \& Braaten, 2008). In this model knowledge production is presented as an individual discovery in which scientists ask questions, follow a standard method and obtain answers (Pera, ibid.). This is a view that is in striking contrast to the contemporary views of 13 well-established scientists (Wong, \& Hodson, 2009). Wong and Hodson (ibid.) concluded that scientists view their practice as community-bound and culture-based. Moreover, they stated that knowledge production occurs in the discourse between members of the community. Pera (ibid.) depicts such knowledge production in the dialectical model and argues that knowledge represents the agreement of the scientists in the community, and in this sense, the scientists together invent rather than discover nature.

Participation of students in a scientific research community aims at student learning and therefore requires an educational model to inform our study. For student inquiry-based learning in secondary science classes various studies propose to create a community of learners in class (Brown, \& Campione, 1996; Crawford, Krajcik, \& Marx, 1998; Engle, \& Conant, 2002; Shulman, \& Sherin, 2004). Brown and Campione (ibid.) indicated that in such a community of learners, students are constantly involved in a recurring reflective cycle of 
carrying out inquiry, sharing results, and applying conclusions with all three of these activities related to key concepts from the scientific domain (see Figure 1).

[Insert Figure 1 about here]

The assumption behind the community of learners model is that students' inquiry learning will be fostered by their involvement in carrying out inquiry if the inquiry process in their science classes resembles a scientific research community.

If the core of a community of learners model is that students carry out inquiry tasks and become actively involved in scientific research, then students should be considered as serious participants in the process of scientific knowledge development. A process that should be the responsibility of students and scientific researchers (Richmond, \& Kurth, 1999). Moreover, if students become involved in research on key questions in the respective science domain, then they should have access to all relevant scientific resources and apparatus (Lave, \& Wenger, 1991). They need to become familiar with the way of collaboration and communication in a scientific research community (e.g., Driver, Asoko, Leach, Mortimer, \& Scott, 1994). In addition, if students participate in scientific research, demands are made upon their ability to be critical of the research process they are involved in. Students have their thoughts of and opinions on the way scientific research occurs and according to Mayer (2004) students start reflecting when they notice that their views show conflict with reality. Reflection could start as a more or less unintentional process by a feeling of discomfort (e.g. Schön, 1983) when incongruence occurs between expectations about and experiences in a scientific research practice. However, when reflection is seen as an ability to look forward and backward in order to do something with a conflicting view then reflection could be an intentional process of premeditated and directed effort (Brown, \& Campione, 1996). 
From the assumption behind the community of learners model and its derived propositions we decided to design a scientific research community that is based on the following principles:

1. Serious partnership in the process of knowledge development

2. Knowledge development occurs by doing scientific research

3. Key questions in the respective science domain are central

4. Acquaintance with collaboration and communication in a research community

5. Critical judgement by reflection

6. Access to scientific resources and apparatus

\section{Student discipline-specific content learning, interest in research and knowledge on NOS}

In this study upper secondary chemistry students participate in a pharmacochemistry research on anti-allergy medicines by means of designing, synthesising and testing medicines or ligands that can block the production of histamine, an organic nitrogen compound that triggers inflammatory response in the human body. For student discipline-specific content learning we consider knowledge related to anti-allergy medicines (for example ligand, receptor, blood-brain-barrier). To conceptualise how students learn in a scientific research community, but now in a broader sense than discipline-specific content learning, we build upon the socio-cultural perspective of Lave and Wenger (1991). In this perspective learning is situated in co-participation of all researchers in the community by means of dialogue, interaction and discussion between the members; a community of practice.

Furthermore, in the design part of a prospective medicine the students use a sophisticated molecular modelling computer programme while in the synthesis part they use organic synthesis laboratory apparatus as well as laboratory techniques like melting point measurements. This is why, student research activities will be distinctly different from their 
routine classroom practical work in which the students often just use recipes and simple equipment to do experiments in order to verify theories (Cobb, \& Yackel, 1996; Ritchie, \& Rigano, 1996; Richmond, \& Kurt, 1999). Moreover, from an extensive literature review on inquiry learning and teaching in science education Lunetta, Hofstein and Clough (2007) concluded that secondary science students often follow a well-structured process of identifying problems and formulating questions, designing and planning investigations, collecting and analysing data, and so on. However, scientist hardly use such a well-structured research process in their daily practice (Wong, \& Hodson, 2009).

Sadler, Burgin, McKinney and Ponjuan (2010) found that most studies on apprenticeship programmes, wherein students work with scientific researchers in a research laboratory, address students' interest in science careers (e.g. George, 2006; Gibson, \& Chase, 2002; Osborne, Simon, \& Collins, 2003; Jenkins, \& Nelson, 2005; Bennett, \& Hogarth, 2009), but not their interest in scientific research as such.

Student understanding of NOS is not necessarily achieved when students carry out inquiry activities in the classroom (e.g. Schwartz, Lederman, \& Crawford, 2004; Ford, \& Wargo, 2007). Bell, Blair, Crawford and Lederman (2003) found hardly any change in upper secondary school students' conceptions of scientific investigation and NOS during the time that the ten students were engaged in a eight-week-long research apprenticeship programme. They concluded that just carrying out inquiry activities is not sufficient for change and they suggested as a remedy to embed explicit reflective sessions about scientific research and NOS in the programme. In contrast, Richmond and Kurth (1999) who studied seven upper secondary school students who participated in a seven-week-long residential summer research programme, concluded that the apprenticeship itself as well as the guided reflection in journal writing and regular group debriefing contributed to a greater student understanding of the cumulative and continuous character of scientific knowledge. Moreover, they found that 
because of the collaboration of the students and the researchers in the research community and the degree to which the students could make use of resources within the community contributed to their views of scientific practice and culture.

Few studies report on a significant change in student discipline-specific content knowledge and student improvements in knowledge about NOS (e.g. Charney, Hmelo-Silver, Sofer, Neigeborn, Coletta, \& Nemeroff, 2007) when students are immersed in scientific research practices, but hardly any studies report on student change in discipline-specific content knowledge, change in knowledge about scientific investigation and NOS, and on change in interest in scientific research. That is why we wanted to study these three aspects in upper secondary chemistry students when they participate in a scientific research community, that is designed according to the six proposed design principles derived from a community of learners model.

From a designed pharmacochemistry research community that is based on the six principles we expect that upper secondary students who participate in such a community will gain discipline-specific content knowledge and interest in research as well as knowledge on scientific investigation and NOS.

\section{The designed pharmacochemistry research community}

In four one and half hour meetings, we - a pharmacochemistry researcher from University $\mathrm{XX}$, an experienced upper secondary chemistry teacher from a school in YY and one of the authors - extensively discussed the six proposed design principles. In this setting the teacher's role was to inform the researcher on the students' prior knowledge and abilities (c.f. Keys, \& Bryan, 2001; Eilks, 2003; Lotter, Harwood, \& Bonner, 2007). Moreover, the teacher informed his chemistry classes about the pharmacochemistry research community and asked for ten volunteers to join the community for a six days project lasting six consecutive weeks. 
The outcome for each of the six principles will be briefly described in terms of the activities of the students in the research community.

Regarding principle 1, serious partnership in the process of knowledge development, while still at school the students read a flyer with information that the pharmacochemistry researchers continue to search for anti-allergy medicines for for example hay fever. Moreover, the flyer said that they would design and synthesise substances, prospective anti-allergy medicines, that have never been synthesised before and that they would discuss the results of their research in a poster session. Furthermore, the flyer told them that they would be working with three researchers from the pharmacochemistry research community at University XX. Before the start of the first meeting at our university the students told us that they understood the information on the flyer and that it made them enthusiastic and curious about the pharmacochemistry research.

For principle 2, knowledge development occurs by doing scientific research, at the first meeting at the university the students, who were divided into two groups, made an association map using provided concept cards. Both maps showed that students were able to associate cards with concepts like hay fever, syndrome, source and anti-allergy drug, but that they experienced problems in associating cards with concepts depicting the brain, neurons, receptors and ligands. These outcomes were used by one of the pharmacochemistry researchers to teach the students, in a lecture called 'why drugs do work', the working of an anti-allergy medicine on a cellular and molecular level in a human body. Moreover, the lecturer focused on ligands or histamine antagonists that fit on receptors in cell membranes so that the production of histamine in the cell is minimized and on the research to find optimal ligands that fit and block the histamine $\mathrm{H}_{1}$-receptor but cannot pass the blood-brain-barrier, since these ligands should not interact with brain cells. 
Furthermore, the students discussed current models for histamine receptors in cell membranes by studying an article by De Esch, Thurmond, Jongejan, \& Leurs (2005), who are pharmacochemistry researchers at University XX.

During the design process the discussion of principle 2 unintentionally revealed that the chemistry teacher and the pharmacochemistry researcher adopt different stances as to the function of laboratory work in a community of learners. The teacher sees laboratory work in chemistry as a means to teach students a particular concept, as just one of the teaching methodologies. On the other hand, the pharmacochemistry researcher sees laboratory work as a means of understanding what kind of knowledge the research will reveal as well as getting to know how researchers think and work. This discussion concluded with the proposal that the teacher should join the research community as a participant.

Regarding principle 3 , key questions in the respective science domain are central, the students and researchers discussed in three groups why cetirizine, the active substance in the anti-allergy medicine, Zyrtec ${ }$, acts as a ligand to fit and block the histamine $\mathrm{H}_{1}$-receptor but cannot pass the blood-brain-barrier. Moreover, the groups made predictions with the use of the histamine $\mathrm{H}_{1}$-receptor model as is shown in the article of De Esch et al. (2005). They considered whether variations in the carbon atom chain in the $-\mathrm{N}-\left(\mathrm{CH}_{2}\right)_{\mathrm{n}}-\mathrm{COOH}$ group of cetirizine can lead to ligands with an improved bonding capacity to the histamine $\mathrm{H}_{1}$-receptor, the latter being the research area in the pharmacochemistry community.

For principle 4, acquaintance with collaboration and communication in a research community, the students worked in teams of two with the three pharmacochemistry researchers. Each team used a modelling computer programme to build two different molecular structures of varied cetirizine molecules, that were predicted as promising ligand substances but had never been synthesised and tested in the laboratory before. Then, the teams tested each molecular structure proposed by letting the computer programme, that contained a 
model of a membrane with a histamine $\mathrm{H}_{1}$-receptor in it, calculate the bonding capacity between the cetirizine-like molecule and the receptor. After that each student synthesised and purified in the laboratory one of the ligands that had a satisfactory bonding capacity. At this stage of the project the students, in cooperation with the three researchers, used standard organic synthetic pathways and procedures to purify the solid substances produced. Moreover, each student verified the purity of the produced substance by a melting point measurement. All pure substances were then sampled by the pharmacochemistry researchers and subjected to mass spectroscopy. Then, the spectra were used in the teams to verify the structures of the various substances. After the decisions that the substances were pure and had the correct structures, the bonding capacity of each substance was determined in vivo. These measurements were done by the pharmacochemistry researchers because in this part of the research the safety rules do not allow the students to work in those laboratories. The bonding capacities of all synthesised substances or ligands in relation to the membrane model were discussed online with all members of the research community.

For principle 5, critical judgement by reflection, the teams prepared a poster on their part of the research. In a poster session held within the faculty-wide pharmacochemistry research community, the students presented and discussed their results in relation to all bonding capacities that were found and to the current model of the histamine $\mathrm{H}_{1}$-receptor.

For principle 6, access to scientific resources and apparatus, the students had access to all relevant scientific resources via an electronic learning environment. This Blackboard ${ }^{\mathrm{TM}}$ environment provided all tasks for the students. The students used it to submit their written assignments. It served as a platform for the instructions and safety rules in the laboratory and was used to present and discuss the results online. Moreover, the students had access to the same apparatus and library resources as the pharmacochemistry researchers. 
The main student activities during their six weeks of participation in the pharmacochemistry research community are summarized in Table 1.

\author{
[Insert Table 1 about here]
}

\title{
Methods, data collection and analysis
}

One upper secondary school was selected for participating in our study. This selection was based on two main criteria: it needed to be a school in the neighbourhood of University XX and the willingness of the chemistry teacher and ten of his students to participate in our study was important. The teacher had more than 25 years of chemistry teaching experience at upper secondary level and all students, age 16-17, were high ability students with two years of upper secondary chemistry education, but with hardly any experience in carrying out inquiry in chemistry classes. The motive for the pharmacochemistry researchers to join our study was twofold. Firstly, they expected to obtain research data in a very short time for ten substances or ligands related to the current histamine $\mathrm{H}_{1}$-receptor model. Secondly, they were eager to show students, who still need to decide on their further education, that becoming a scientist is a good option.

In the study a combination of research instruments (Cohen, \& Manion, 1994) with triangulations of data sources (Yin, 1994) was chosen, because we wanted to determine whether the six proposed design principles were successful in bridging the gap between a secondary school inquiry practice and a scientific research practice as well as whether any change occurred in student discipline-specific content knowledge, knowledge about research activities and NOS, and interest in scientific research.

For each research question, the instruments and the procedures of collecting and analysing the data are described in the next paragraphs. 


\section{The design principles}

In week 6 of the project the ten students (S1-S10), their teacher (T) and three faculty researchers (R1-R3) were individually interviewed and asked to reflect on the extent to which each of the six design principles had been successfully brought into practice. Moreover, in the interviews with the teacher and the pharmacochemistry researchers an extra question was asked about whether any principle was missing in the design. All interviews were audio taped and transcribed. Firstly, the fourteen transcripts were individually read by two of the authors. During this reading process a response was indicated with $(\sqrt{ })$ when the interviewee expressed no doubt regarding the achievement of a particular design principle. Responses with some doubt were indicated with $( \pm)$ and responses full of doubt with (-). Secondly, the indications in the ten student transcripts were separately assigned for each of the six design principles with 10 when all students agreed and with for example 4 when four students agreed on the achievement of a particular design principle. The same was done with the indications of the teacher and the three researchers.

Field notes were made by one of the authors for the instructional strategies of all the pharmacochemistry researchers in week 1-6 by recording all activities of the researchers at each session. Moreover, all these activities were videotaped by the note-taking author. Furthermore, another author observed four randomly chosen students (named S1, S2, S3 and S4) in pairs during their main activities in week 1-6. The observations included the recording of what the four students did on a certain day at a specific time. Those four students were also videotaped during the main activities. The videotaping was monitored by the author who also did the capturing of the researchers' instructional activities. The sections where the analysis of the data regarding the six proposed principles in each group of participants showed discrepancies were compared with the written field notes and the relevant transcribed video tape recordings. 
All data analyses were compared by two of the authors and discussed until consensus was reached (Janesick, 2000).

\section{Student change}

To determine change in student discipline-specific content knowledge, student knowledge about scientific investigation and NOS as well as change in student interest, we used a questionnaire, a semi-structured interview and the earlier mentioned video recordings in our study.

The questionnaire, that was filled in by all ten students in week 1 and 6 of the study consisted of three Parts (I-III); see the Appendix.

In Part I of the questionnaire the students answered ten open questions that are related to discipline-specific content knowledge. For each question an answer led to a mark between 0 and 10. The total scores of the students in week 1 and 6 were averaged for each question and for all questions as well as for the change between week 1 and 6.

In Part II of the questionnaire the students rated, on a four-point Likert scale, eleven statements on interest in scientific research. For some examples see Part II of the Appendix.

This part of the questionnaire was piloted previously with 68 upper secondary chemistry students (age 16-17) from the same school $(\alpha=0.82)$ since it was set by the authors who wanted to assure the reliability and validity of this part of the questionnaire.

All student ratings were allocated 1,2, 3 or 4 points, then all points for each statement in the questionnaire were added and averaged. Followed by a comparison of the students averaged scores in week 1 and week 6.

In Part III of the questionnaire the students answered six open questions (see Part III of the Appendix). In the first question the students were asked to write down as many activities as possible that they consider to be scientific investigation activities. Then, they answered four 
questions concerning scientific knowledge, scientific theories, difference between a scientific theory and a scientific law, and creativity and imagination of scientists. These four questions were taken from the Views of Nature of Science Questionnaire Form C (VNOS-Form C; Abd-El-Khalick, 2006). Finally, they answered question 6 on: 'Why do scientists use models?'

The answers of the ten students to the six questions were analysed in different ways. First for question 1 , the average number of research activities given by the students in week 1 was compared to those given by the students in week 6. Secondly, two researchers categorised the student written responses (to question 2-6) as a naïve understanding (a correct answer but an incorrect reasoning) and an informed understanding (a correct answer and a correct reasoning) analogous to Abd-El-Khalick (2006).

In week 6, three days after the presentations, the four randomly selected students (S1S4) were individually interviewed by one of the authors. Each interview took about two hours. During the interview the written responses in the questionnaire from week 1 and week 6 as well as the video tape of that student were at hand. First, we pointed out to the interviewee where he made changes regarding the questions in Part I, II and III of the questionnaire. Second, we asked the question 'what caused the change?' Then, if possible, we looked up the relevant video recording and asked the interviewee to "explain why he changed his mind?' The four interviews were audio taped and transcribed.

All data analyses were done by two of the authors and discussed until consensus was reached (Janesick, 2000).

\section{Results}

First, the results of the achievement of the proposed six design principles for the pharmacochemistry research community are presented. Then the results are shown of change 
in student discipline-specific content knowledge, student interest in scientific research and in student knowledge on scientific investigation and NOS.

\section{The design principles}

The analysis of responses of the ten students, their chemistry teacher and the three pharmacochemistry researchers in the interviews during week 6 reveals that all participants expressed no doubt regarding design principle 2, knowledge development occurs by doing scientific research, principle 4 , acquaintance with collaboration and communication in a research community, and principle 6, access to scientific resources and apparatus. Moreover, the analysis reveals that the teacher expressed no doubt regarding all design principles. However, differences were identified in the responses of the students regarding design principle 3, key questions in the respective science domain are central, as well as in the responses of the researchers on design principles 1, serious partnership in the process of knowledge development, and 5, critical judgement by reflection. For the analysis of all responses see Table 2 .

[Insert Table 2 about here]

Our analysis shows that four students (S4, S7, S8 and S10) indicated some doubt regarding the achievement of design principle 3 , key questions in the respective science domain are central. An example is shown from the transcript of one the interviewed students (S4):

I found it a very intriguing research question and they [the researchers] told me that their research is in a crucial area of getting to know more about allergies and how to stop them. I 
see the relevance of this research, but by now I really do not know whether studying these processes in the [cell] membrane are the most important ones in their area.

Further analysis of the field notes does not give more information on design principle 3. However, the transcript of the part on the video tape in which student (S4) and researcher (R2) are talking about the relevance of the research reveals that the student asked for the main reason of the research, but does not receive an adequate answer. The transcript is as follows:

S4: Yes, I understand the importance of helping people who suffer from hay fever, but what is the overall reason [of your research]?

R3: To know more about processes in the cell membrane, what molecules trigger or stop a process inside a cell.

S4: So, all researchers in your division look at models of cell membranes?

R3: $\quad$ Yes, $\ldots$

In the analysis of the researchers' interviews also some doubt was identified in one of the responses of the pharmacochemistry researcher (R2) regarding design principle 1, serious partnership in the process of knowledge development, as is shown in the following quote:

R2: Especially in the laboratory. At a certain moment during the instruction, they [the students] started a discussion on acids, bases and on our accepted procedure of synthesising a ligand. At that time I was astonished about their lack of knowledge. I just instructed them what to do instead of creating room for a discussion on the zwitterionic character of the various histamine $\mathrm{H}_{1}$-ligands related to the predictions of histamine $\mathrm{H}_{1}$-receptor model. I think I did this because of time pressure. 
One of the students [S7] unexpectedly got a liquid instead of a [predicted] solid [ligand]. This student saw that all other students got solids. This fact did neither trigger reflection by the student on the research method, the prediction, or hypothesis related to the model nor bring about a critical attitude of the student. The student just seemed to be worried of not finding a correct answer.

Further analysis of the field notes and videotapes does not give more information on the issue of principle 5 .

Finally, the interview responses of the teacher and the three pharmacochemistry researchers show that they experienced no missing principles in the design of a research community that was based on six design principles derived from an educational model of a community of learners.

\section{Student change in discipline-specific content knowledge}

The total average of the student scores in Part I of the questionnaire worth 10 points, showed an increase of 4.94 points; from an average score of 2.73 points scored by the students in week 1 to 7.67 points, scored by the students in week 6 (see Table 3 ). 
[ Insert Table 3 about here]

From the comparison of the written responses in week 1 and week 6 from the questionnaires of students S1-S4 we noted that all four students had a correct change of response for question 1 (what is a ligand?) and 2 (what is a receptor?). Moreover, students S2 and S4 had a correct change for question 3 (Describe in brief how cells communicate). From the interview data we obtained that these changes were mediated by one of the pharmacochemistry researchers, who gave a lecture in the first meeting (week 1) immediately after the students made an association web with provided concept cards. As student S4 expressed it:

In our group we did not know what to do with those cards [cellular and molecular level], but after she explained it [in the lecture] I understood the meaning of a ligand, receptor and also how cells communicate.

The concept of a spacer (question 8) and how the bonding capacity of the ligand is measured (question 10) also changed for all four students to a correct answer in the written responses from week 6. The interview data indicated that they had grasped the concept of a 'spacer' when they did the modelling activity in week 2 . The correct answer to question 10 was acquired by students S1 and S3 through the online discussion in week 5 and by students S2 and S4 during the preparation of the poster presentation in week 6.

\section{Student change in interest in scientific research}

From all student responses in Part II of the questionnaire we observed that none of the eleven statements had a negative change (see Table 4). As shown in Table 4 positive changes 
I thought of studying economics, so I was not so eager to learn about scientific research, but in fact there are two reasons why I changed my mind. I am very excited about hovering between what we know and what we do not yet know and during lunchtime I also talked to some of the master students about their experiences in studying biomedicine. That is why I changed my mind and therefore I also changed my choice of what to study at university. I think I will opt for a study in chemistry or biophysics.

Furthermore, student S2 expressed his change of response to statement 11 like this:

It was such an interesting experience, the discussions, the new stuff, for example how long it takes to have a new medicine. I want to be part of that world, so I am really convinced I want to become a scientist and not a lawyer. I really like the way they [the pharmacochemistry researchers] approach problems. Their world is exciting and requires patience, that is what I like. 
Student S3 responded, regarding statement 8, as follows:

\begin{abstract}
I wish I could have put a 'fully agree' on some of those [the statements]. It was great to be part of real research. For example, the labs and the apparatus and also all the discussions we had. You know you can just talk to them [the pharmacochemistry researchers]. Before the project I thought they would be more like nerds. I hope our teacher also learned something so that we have more real practical work in class [statement 8]. Normally I am a bit ahead in our [text]book so the experiments we do in class are really very eh very dull.
\end{abstract}

Lastly, student S4 changed his views on statements 3 and 5 as is evidenced by:

It was a great experience to be here at your university. I changed [statement] 3 to agree and [statement] 5 to disagree, because at school I sometimes feel that the work in the lab is very dull. We just copy what is in the [text]book. Here our work was exciting and for the first time I was really challenged in my thought process. I learned a lot in a short time.

\title{
Student change in knowledge on scientific investigation and NOS
}

In Part III, regarding question 1 "write down as many activities you consider to be scientific investigation activities", the average number of investigative activities that were mentioned by the students increased from 5.5 (week 1) to 8.7 (week 6).

In week 1 the students referred to activities, such as: 'formulating research questions', 'planning and conducting experiments', 'finding results', 'inferring conclusions' and 'writing reports'. The increase in week 6 was brought about by additional activities related to models 'using and adjusting models', to creativity 'thinking about various aspects of unexpected outcomes' and to communication 'not only presenting results but also discussing the results with peers and other researchers'. Furthermore, from a comparison of the students' written 
responses (from S1-S4) in week 1 and week 6 we noticed that student S1 and S4 added extra investigative activities. In the interview S1 expressed it as follows:

At school we learn the scientific method, which is a stepwise process. That is why I wrote down those ones [written responses in week 1]. But now I understand that it is not like that. I experienced research as a hotchpotch that you have to think over and over. We only used the steps in our poster.

And this is how student S4 expressed it in the interview:

I now think that communication is very important, because I saw that they [the pharmacochemistry researchers] kept on talking about our results and they argued about what other researchers would think of a possible overlap between two models.

Students S2 and S3 did not add extra investigative activities in their written responses in week 6. Both reasoned in the interview like this:

Those were the items we used to prepare our research poster. We also use those at school.

The students' written responses to question 2 indicated that in week 1 all ten students thought that the only way to develop scientific knowledge was through experiments. The examples they wrote down were for example 'electrolysis' (S1), 'mixing alcohol and water' (S4) and 'making aspirin' (S8). However, seven students indicated in week 6 that observation also can lead to scientific development. These are, for example, two responses: 
S9: Not always, I believe that not only observations but also thinking can give knowledge development in the sciences. For example with the black holes they cannot do experiments.

S10: No, some problems, for example the carbon dioxide pollution in our world, are so complex that scientists cannot do valid experiments.

Two of the remaining students (S5 and S6) again responded that experiments are the only way to develop scientific knowledge and one student wrote:

S8: Experiments are not carried out to develop knowledge but to verify knowledge, like we did with the predictions we made with the membrane model.

From the interview transcripts we obtained the following quotes about question 2:

S1: I changed because during the modelling [activity] I realised that some parts in the model are assumptions and do not come from experiments;

S3: Experiments are not always possible, because sometimes the problem is too complex to handle all the variables. I changed my mind when we [with student S10] discussed aspects concerning climate change, which was when long-term observations could help to find explanations;

S4: We do real experiments in which we control everything and we do thought experiments based on observations; both are needed to further build on our knowledge. I changed because I discussed this with my teacher, who told me that you need both.

The students' written responses to question 3 showed that in week 1 all ten students think that a scientific theory does change. Some responses: 
S1: Yes, theories can change. Like the evolution theory has changed over the years.

S4: Yes, theories can change. The atomic theory developed because scientists build on the knowledge of their predecessors every time.

In week 6 all students again wrote that a scientific theory can change. The responses of four students, S1, S2, S3 and S8, changed:

S1: Yes, they change. In the beginning of the project I thought that most scientific theories, like the evolution theory, changed in earlier days and are stable by now, but now I think that scientists have another meaning to that word than I had at that time;

S2: They change. I now see a theory as something that is accepted by scientists;

S3: Yes, I think that a theory can change but some theories (for example the atomic theory) resists, for the time being, attempts to disprove them;

S8: A definite yes, theories are susceptible to new evidence. Scientists constantly think them over.

Further evidence for students' ideas about scientific theories was provided by their responses in the interview, abstracts of which are quoted below:

S1: As I understood from him [R3] theories are explanations and I think they can change when you know more;

S2: During the synthesis of the ligand we had to wait so we had a discussion with I. [R2] and K. [student S1] on theories and from that I learned that an explanation is in fact a theory; 
S3: $\quad$ The ligand I synthesised in the lab did not show the bonding capacity as was expected by the calculations of the computer, so in the poster presentation it became clear to me that we disproved something, so maybe the theory can change;

S4: When you know more about how a ligand works you can change the theory of the interaction between a ligand and a receptor and how it affects the inside of a cell.

In week 1 all students' written responses to question 4 relate to the consideration that theories later on when there is more evidence become laws. By week 6 , the student responses except for student S1's response did not show any change. In week 6 student S1 wrote:

In the interview student $\mathrm{S} 1$ responded as follows:

I first thought that more evidence always leads to a law, but now I think, because of I. [R2] who convinced me, that more evidence gives better explanations. Whereas I consider a law as something that when you do A it always will lead to B; like an apple will always fall down.

Students S2, S3 and S4 all expressed it in the interview more or less like:

Yes, more evidence will always lead to laws, because like Ohm's law came from many experiments that all came to the same conclusions.

Student responses to question 5 showed that all students in week 1 think that creativity and imagination is 'not done', because like four of them (S1, S3, S6 and S8) wrote: 'science should be objective, not subjective'. However, all ten students felt in week 6 that scientists need creativity and imagination. Some written responses are: 
S6: Yes, because for explanations you need to have ideas that come from your brains as well as out of discussions with your peers;

S8: Yes, when one of us in the lab got a liquid instead of a solid I saw the function of creative thinking immediately the question why was asked and they [R1, R2 and R3] started imagining all kinds of explanations.

Quotes from the interviews confirm these ideas:

S2: You know I first thought of something like a kind of creative bookkeeping and that is not allowed in research. But by the time that we [S2 and S7] had to prepare our poster we discussed that for each and every part in a research you need to be creative. I mean not in a sense that you mislead other researchers but that you keep on thinking and also keep on using your imagination;

S3: At the start of the project I felt that researchers should be honest people. They cannot just direct what results should come out of their research. But now I think that researchers should be creative. Especially when I ran into problems with some of the glassware we used. Then they came up with a good solution;

S4: I changed because I had a discussion with I. [R2]. He said that Einstein used a lot of imagination and creative thinking when he developed $\mathrm{E}=\mathrm{mc}^{2}$. I also talked about it with my mother [who is a dentist]. I experienced a big difference between our chemistry lab work at school and real research. At school we just verify things like we did in electrochemistry, but now I saw how they think.

Regarding the students' written responses to question 6, all ten students referred in week 1 to scale models: 'so to have an idea how molecules are ... like the [molecular] model boxes 
we have at school to build methane', whereas in week 6 all students' written answers contained the notion of the predictive function of models.

The responses in the interviews were all related to the predictive function of models in relation to the results of the bonding capacity of the synthesised ligand to the cell membrane, a change that according to the students came through the activity of predicting with and reflecting on the model. As S1 expressed it:

We used the model to predict and the results of the experiments to reflect on the model, because it [the model] catches part of a reality.

The results of the categorised students' responses to question 2-6 (Part III of the questionnaire) are summarised in Table 5.

[Insert Table 5 about here]

\section{Discussion, conclusion and implications}

\section{Design principles}

The first research question in our study was: "which design principles are necessary to have a successful participation of upper secondary chemistry students in an authentic research community?' Firstly, using the six principles (1-6) that are proposed by the community of learners theory we succeeded in designing an authentic research community project in which we expected that upper secondary chemistry students could successfully participate. Secondly, data from the interviews with the chemistry teachers and the three pharmacochemistry in week 6 show that no new design principles came up.

Using the data obtained in the interviews regarding the experiences of the different participants in the research community on whether the six intended design principles were successfully brought into practice, it can be concluded that in general most of the principles were experienced as intended by most of the participants (see Table 2). However, for 
principle 1, serious partnership in the process of knowledge development, we conclude that, at that particular time, there was a mismatch between one of the pharmacochemistry researchers and the students regarding the level of the students' understanding of the various histamine $\mathrm{H}_{1}$-ligands and the histamine $\mathrm{H}_{1}$-receptor model. A reason for this mismatch could be that this researcher expected that the lecture at the start of the project was sufficient for the students to understand these. Moreover, for principle 5, critical judgement by reflection, the interview data show that one of the pharmacochemistry researchers realised that an unexpected result was not enough to start a process of reflection within one of the students. An explanation could be that this particular student reflected his experiences from laboratory work at school, for example they do laboratory work to verify a concept, they hardly are challenged to think critically, and they just try to give a right answer. The first example, students do laboratory work to verify a concept, maybe reflects his teacher's view on the role of laboratory work. A view that was visible during the process of designing the research community, in which the teacher views laboratory work as a kind of methodology to develop concepts. That teachers view laboratory work as a means to develop concepts only was also concluded by Gyllenpalm, Wickman and Holmgren (2009).

Furthermore, from the student interview data, it is concluded that regarding principle 3, key questions in the respective science domain are central, four students understood the question under research in the pharmacochemistry community but felt that a bigger view regarding the science domain was not clarified for them. This is probably due to the fact that the pharmacochemistry researcher at that time in the laboratory was not aware of the gap between the thinking of the student who focussed on the macro-level ('helping people who suffer from hay fever') and his own thinking that focussed on the micro-level ('what molecules trigger or stop a process in a cell').

In conclusion, the six principles in general seem to be feasible for designing an authentic research community that can bridge the gap between science laboratory work at upper secondary school and research at university.

Student discipline-specific content knowledge and interest in scientific research as well as knowledge on investigative activities and NOS

The second question in our study was: "what changes occur in the students' disciplinespecific content knowledge and interest in scientific research as well as knowledge on scientific investigation and NOS by working in such a designed community?" 
Using the results obtained from the student data in Part I of the questionnaire, we conclude that the discipline-specific content knowledge of all students increased (see Table 3). The most remarkable increase in their knowledge regarded questions 10, explain how the bonding capacity of the ligand is measured, and 7, explain the working of a medicine on cellular level. Hence, participation in the pharmacochemistry research community enhanced discipline-specific content knowledge development within all students.

From the student interview data, we conclude that the following activities enhanced student discipline-specific content knowledge:

(i) the 'concept mapping' activity followed by a lecture. In this activity the students realised that they had gaps in their knowledge regarding the cellular and molecular level. This awareness raised their anxiety about the pharmacochemistry research;

(ii) the 'modelling' activity. This activity enhanced the student understanding of the concept of a spacer, because the students individually built a variation of the spacer part in a cetirizine-like molecule; and

(iii) 'reflective' activities such as the online community peer discussion of the results from the in vivo experiments and the preparation of their research poster.

Regarding student interest in scientific research the obtained data in Part II of the questionnaire show small but positive changes for statements 1, 3, 5, 8 and 11 (see Table 4). Remarkable is that the students gave the highest possible score for statement 10 that says 'I find scientific research interesting'. Moreover, at the start of the project the average student interest ratings on the eleven statements were already quite high; 3.47 on a four-point Likert scale. We think that this high value is due to the fact that the students who participated in our study did this on a voluntary basis and in fact were already, as is shown by the results of statement 10 , very interested in scientific research. When we take this into account, then the average student interest rating to 3.60 at the end of the project is remarkable since to increase the interest of already highly-motivated students is not likely to be easy.

The student interview quotes, regarding Part II of the questionnaire, show that the student changes in interest were mainly brought about by talking to other students at the university, by actually participating in the field of scientific research, by experiencing the environment at the university as exciting, by facing the challenges of and problems in scientific research as well as by experiencing the research culture. The follow-up of the two students who said that they wanted to change to a science career, revealed that one student studies biophysics and the other student studies chemistry. 
From the students' written answers to question 1, that were obtained from Part III of the questionnaire, we conclude that at the end of the project the students were able to refer to more investigative activities. Some students recognise that scientific research is not just a method or a stepwise process, whereas some students still consider it as a good structure to do investigative work and to prepare a poster. Moreover, some students realise that the researchers judge the status of method and of scientific knowledge in the context of its use.

Based on the written responses regarding student knowledge on NOS in Part III of the questionnaire (see Table 5) and on the student interview data, we conclude that all students changed toward an informed view regarding two NOS aspects, namely 'creativity and imagination' and 'models'. The change on the first aspect occurred through reflective moments during discussions, by seeing a completely different attitude of the pharmacochemistry researchers when unexpected results (for example the formation of a liquid) came up. The researchers discuss possible explanations for unexpected results in stead of rigging results so that they fit the predictions. Therefore, role modelling by researchers seems to be a crucial element to enhance a change. The student change of the second aspect occurred through predictive and reflective activities regarding the histamine $\mathrm{H}_{1}$-receptor model. Hence, a community-wide peer prediction on the outcome and peer reflection on the results and the method in relation to the model under research appeared to be an effective approach to change students' views on models.

Table 5 shows that change in students' views on the difference between a theory and a law was difficult to achieve. Only one student (S1) changed to an informed view, and this was as the student interview data show, because of a discussion with one of the pharmacochemistry researchers. The other students did not change their views, because the synthesis of a ligand is probably not a good example of being confronted with the difference between a theory and a law in laboratory work. As such this question is not so relevant for our study. More explicit reflective discussions could, according to Yacoubian and BouJaoude, 2010, be more effective in changing student views regarding the difference between a theory and a law.

For the other two NOS aspects 'requirement of experiments' and 'change in theory' we obtained mixed results (see Table 5). From these results we conclude that it is difficult for students to change these aspects. Even their serious involvement in and ownership of the research was not enough for some of the students to change their views on these two aspects, which shows that the students should probably be more involved in activities that show that experiments are not the only route to scientific knowledge, but also show the role of 
induction. In order to create student awareness on the idea that scientific knowledge is based on the non-observable as well. Moreover, students could do activities regarding the difference between non-tentative scientific facts and tentative scientific theories.

Of course, awareness is needed that participation of students in a scientific research community, that brought about the change in students' interest in scientific research, is difficult to achieve in common upper secondary schools (Buxton, 2006). Nevertheless, looking at the results in which the students express their experiences with laboratory work at school, we agree with Millar, \& Abrahams (2009) that it is a necessity to change the way practical work is presented at secondary schools.

In line with Wong, \& Hodson (2009) and based on our study, we argue that in upper secondary schools, science students should carry out some predictive and reflective modelling activities, have peer reflection on experimental data in relation to models, carry out activities related to scientific knowledge development, use induction and carry out activities related to the practices (Hsu, van Eijck, \& Roth, 2010) as well as motives of scientific researchers.

Appendix: The student questionnaire with Part I, some examples of Part II and Part III

Part I : Discipline-specific content knowledge

1. What is a ligand?

2. What is a receptor?

3. Describe in brief how cells communicate.

4. What is a histamine $\mathrm{H}_{1}$-receptor?

5. What does a histamine $\mathrm{H}_{1}$-receptor set in motion inside a cell?

6. What is the function of a blood-brain-barrier?

7. Explain the working of a medicine on cellular level.

8. What is a 'spacer'?

9. How do you know whether a synthesised ligand is not a mixture anymore?

10. Explain how the bonding activity of the ligand is measured.

Part II: Interest in scientific research; some examples

1. I like to learn how to do scientific research

0 disagree

0 disagree a bit

0 agree a bit

0 agree 
1

2

3

4

5

6

7

8

9

10

11

12

13

14

15

16

17

18

19

20

21

\author{
3. I like to do scientific research \\ 0 disagree \\ 0 disagree a bit \\ $0 \quad$ agree a bit \\ $0 \quad$ agree \\ 5. Doing scientific research is dull \\ $0 \quad$ agree \\ $0 \quad$ agree a bit \\ 0 disagree a bit \\ 0 disagree \\ 8. I wish we could do more investigative work in class
0 disagree
$0 \quad$ agree a bit
$0 \quad$ agree \\ 0 disagree a bit \\ 11. I wish to have a scientific career
0 disagree
0 disagree a bit
0 agree a bit
$0 \quad$ agree

Part III : Knowledge about scientific investigation and NOS; some examples

1. Write down as many activities possible that you consider to be scientific investigation activities.

2. Does the development of scientific knowledge require experiments? Explain your answer. (VNOS-Form C; question 3)

3. After scientists have developed a scientific theory (for example atomic theory, evolution theory), does the theory ever change? Explain your answer. (VNOS-Form C; question 4)

4. Is there a difference between a scientific theory and a scientific law? Illustrate your answer with an example. (VNOS-Form C; question 5) 
5. Do scientists use their creativity and imagination during their investigations? Explain your answer. (VNOSForm C; question 8)

6. Why do scientists use models?

\section{References}

Abd-El-Khalick, F. (2006). Over and again: college students' views of nature of science. In L.B. Flick \& N.G. Lederman (Eds.) Scientific inquiry and nature of science. Implications for teaching, learning and teacher education (pp. 425). Springer, Dordrecht.

Barab, S.A., \& Hay, K.E. (2001). Doing science at the elbows of experts: Issues related to the science apprenticeships. Journal of Research in Science Teaching, 1, 70-102.

Bell, R., Blair, L., Crawford, B., \& Lederman, N. (2003). Just do it? Impact of a science apprenticeship program on high school students' understandings of the nature of science and scientific inquiry. Journal of Research in Science Teaching, 40, 487-509.

Bennett, J., \& Hogarth, S. (2009). Would You Want to Talk to a Scientist at a Party? High school students' attitudes to school science and to science. International Journal of Science Education, 31, 1975-1998.

Brown, A.L. \& Campione, J.C. (1996). Psychological theory and the design of innovative learning environments: on procedures, principles, and systems. In L. Schauble \& R. Glaser (Eds.) Innovation in learning: New environments for education (pp. 289-325). Mahwah, NJ: Lawrence Erlbaum Associates, Inc.

Buxton, C.A. (2006). Creating contextually authentic science in a "low performing" urban elementary school. Journal of Research in Science Teaching, 43,659-721.

Charney, J., Hmelo-Silver,C.E., Sofer,W., Neigeborn,L., Coletta, S., \& Nemeroff,M. (2007). Cognitive apprenticeship in science through immersion in laboratory practices. International Journal of Science Education, 29, 195-213. 
Cobb, P., \& Yackel, E. (1996). Constructivism, emergent and sociocultural perspectives in the context of developmental research. Educational Psychologist, 31, 175-190.

Cohen, L., \& Manion, L. (1994). Research methods in education (pp. 233-251). London: Routledge.

Crawford, B.A., Krajcik, J.S., \& Marx, R.W. (1998). Elements in a community of learners in a middle school science classroom. Science Education, 83, 701-723.

De Esch, I.J.P., Thurmond, R. L., Jongejan, A., \& Leurs, R. (2005). The histamine $\mathrm{H}_{4}$ receptor as a new therapeutic target for inflammation. Pharmacological Science, 26, $462-$ 469.

Driver, R., Asoko, H., Leach, J. Mortimer, E.F., \& Scott, P. (1994). Constructing scientific knowledge in the classroom. Educational Researcher, 23, 5-12.

Driver, R., Leach, J., Millar, R., \& Scott, P. (1996). Young people's images of science. Buckingham, England: Open University Press.

Eilks, I. (2003). Co-operative curriculum development in a project of participatory action research within chemical education: teachers' reflection. Science Education International, $14,41-48$.

Engle, R.A., \& Conant, F.R. (2002). Guiding principles for fostering productive disciplinary engagement: explaining an emergent argument in a community of learners classroom. Cognition and Instruction, 20, 399-483.

Ford, M.J., \& Wargo, B.M. (2007). Routines, roles, and responsibilities for aligning scientific and classroom practices. Science Education, 91, 133-157.

George, R. (2006). A cross-domain analysis of change in students' attitudes toward science and attitudes about the utility of science knowledge. International Journal of Science Education, 28, 571 - 589. 
Gibson, H.L., \& Chase, C. (2002). Longitudinal impact on an inquiry-based science program on middle school students' attitudes toward science. Science Education, 86, 693-705.

Gilbert, J.K. (2004). Models and modelling: Routes to more authentic science education. International Journal of Science and Mathematics Education, 2, 115-130.

Gyllenpalm, J., Wickman, P., \& Holmgren, S. (2009). Teachers' Language on Scientific Inquiry: Methods of teaching or methods of inquiry? International Journal of Science Education, 32, 1151 - 1172.

Helms, J.V. (1998). Science and/in the community: context and goals in practical work. International Journal of Science Education, 20, 643-653.

Hsu, P-L., Van Eijck, M., \& Roth, W-M. (2010). Students' representations of scientific practice during a science-internship: reflections from an activity-theoretic perspective. International Journal of Science Education, 32, 1243-1266.

Janesick, V.J. (2000). The choreography of qualitative research design. In H.K. Denzin \& Y.S. Lincoln (Eds.), Handbook of qualitative research (pp.379-399). Thousand Oaks, CA: Sage.

Jenkins, E., \& Nelson, N. (2005). Important but not for me: students' attitudes towards secondary school science in England. Research in Science and Technological Education, $23,41-57$.

Kass, H., \& Macdonald, A.L. (1999). The learning contribution of student self-directed building activity in science. Science Education, 83, 449-471

Keys, C.W., \& Bryan, L.A. (2001). Co-constructing inquiry-based science with teachers: essential research for lasting reform. Journal of Research in Science Teaching, 38, 631645. 
Krajcik, J.S., Blumenfeld, P., Marx, R.W., Bass, K.M., Fredericks, J., \& Solloway, E. (1998). Middle school students' initial attempts at inquiry in project-based science classrooms. Journal of the Learning Sciences, 7, 313-350.

Lave, J., \& Wenger, E. (1991). Situated learning: Legitimate peripheral participation. Cambridge: Cambridge University Press.

Lotter, C., Harwood, W.S., \& Bonner, J.J. (2007). The influence of core teaching conceptions on teachers' use of inquiry teaching practices. Journal of Research in Science Teaching, $44,1318-1347$.

Lunetta, V.N., Hofstein, A., \& Clough, M.P. (2007). Learning and teaching in the school science laboratory: An analysis of research, theory, and practice. In S.K. Abell \& N.G. Lederman (Eds.) Handbook of research on science education (pp. 393-441). Mahwah, NJ: Lawrence Erlbaum.

Mayer, R. (2004). Teaching of subject matter. Annual Review of Psychology, 55, 715-744.

Millar, R., \& Abrahams, I. (2009). Practical work: making it more effective. School Science Review, 91, 59-64.

O’Neill, D.K., \& Polman, J.L. (2004). Why educate "little scientist?" Examining the potential o practice-based scientific literature. Journal of Research in Science Teaching, 41, 234266.

Osborne, J., Simon, S., \& Collins, S. (2003). Attitudes towards science: A review of the literature and its implications. International Journal of Science Education, 25, 1049-1079.

Pera, M. (1994). The discourses of science (p. ix). Chicago: University o Chicago Press.

Richmond, G., \& Kurth, L.A. (1999). Moving from outside to inside: High school students' use of apprenticeships as vehicles for entering the culture and practice of science. Journal of Research in Science Teaching, 36, 677-697. 
Ritchie, S.M., \& Rigano, D.L. (1996). Laboratory apprenticeship through a student research project. Journal of Research in Science Teaching, 33, 799-815.

Roth, W.-M. (1996). Knowledge diffusion in a grade 4-5 classroom during a unit of civil engineering: an analysis of a classroom community in terms of its changing resources and practices. Cognition and Instruction, 14,170-220.

Sadler, T.D., Burgin, S., McKinney, L., \& Ponjuan, L. (2010). Learning science through research apprenticeships: a critical review of the literature. Journal of Research in Science Teaching, 47, 235-256.

Schwartz, R.S., Lederman, N.G., \& Crawford, B.A. (2004). Developing views of nature of science in an authentic context: An explicit approach to bridging the gap between nature of science and scientific inquiry. Science Education, 88, 610-645.

Shulman, L.S., \& Sherin, M.G. (2004). Fostering communities o teachers as learners: Disciplinary perspectives. Journal of Curriculum Studies, 36, 135-140.

Schön, D.A. (1983). The reflective practitioner. How professionals think in action. New York: Basic Books.

XX (2004).

XX (2010).

Wenger, E. (1998). Communities of practice, learning, meaning and identity. Cambridge: Cambridge University Press.

Windschitl, M., Thompson, J., \& Braaten, M. (2008). Beyond the scientific method: modelbased inquiry as a new paradigm of preference for school science investigations. Science Education, 92, 941-967.

Wong, S.L., \& Hodson, D. (2009). From the horse's mouth: What scientist say about scientific investigation and scientific knowledge. Science Education, 93, 109-130.

Yacoubian, H.A., \& BouJaoude, S. (2010). The effect of reflective discussions following inquiry-based laboratory activities on students' views of nature of science. Journal of Research in Science Teaching, 47, 1229-1252.

Yin, R. K. (1994). Case studies research: design and methods (pp. 18-77). London: Sage. 
Figure 1. Basic student involvement in a community of learners (based on Brown \& Campione, 1996). 
Table 1 . The main student activities in week 1-6 within the pharmacochemistry research community

\begin{tabular}{ll}
\hline Research community & Main student activity \\
\hline Week 1 & Getting to know the research content and community \\
Week 2 & Building, modelling and predicting the bonding capacity of ligands \\
Week 3 & Synthesising a ligand \\
Week 4 & Purifying and determining purity of the ligand \\
Week 5 & Discussing the bonding capacities \\
Week 6 & Preparing poster and presentation \\
\hline
\end{tabular}


Table 2. The participants' agreement on the achievement of each of the six design principles.

\begin{tabular}{lllllll}
\hline Participants in the & \multicolumn{7}{l}{ The six design principles } & & & \\
research community & 1 & 2 & 3 & 4 & 5 & 6 \\
\hline Students $(\mathrm{n}=10)$ & 10 & 10 & $\mathbf{6}$ & 10 & 10 & 10 \\
Teacher & 1 & 1 & 1 & 1 & 1 & 1 \\
Researchers (n=3) & $\mathbf{2}$ & 3 & 3 & 3 & $\mathbf{2}$ & 3 \\
\hline
\end{tabular}


Table 3. The average student $(n=10)$ scores in question 1-10 for week 1, week 6 and the total scores as well as the average change.

\begin{tabular}{|c|c|c|c|}
\hline Question & $\begin{array}{l}\text { Average score week } 1 \\
\qquad(\mathrm{n}=10)\end{array}$ & $\begin{array}{l}\text { Average score week } 6 \\
\qquad(\mathrm{n}=10)\end{array}$ & $\begin{array}{l}\text { Average change } \\
\qquad(\mathrm{n}=10)\end{array}$ \\
\hline 1 & 2.2 & 7.7 & 0.52 \\
\hline 2 & 5.1 & 8.8 & 0.37 \\
\hline 3 & 2.8 & 6.3 & 0.35 \\
\hline 4 & 2.4 & 7.0 & 0.46 \\
\hline 5 & 5.5 & 8.8 & 0.33 \\
\hline 6 & 3.3 & 6.9 & 0.36 \\
\hline 7 & 0 & 6.1 & 0.61 \\
\hline 8 & 2.8 & 8.0 & 0.52 \\
\hline 9 & 3.2 & 8.2 & 0.50 \\
\hline 10 & 0 & 8.9 & 0.89 \\
\hline Total & 2.73 & 7.67 & 4.94 \\
\hline
\end{tabular}


Table 4. The average student $(n=10)$ scores in statement $1-11$ for week 1 and week $6 . \sqrt{ }$ means a positive change.

\begin{tabular}{|c|c|c|c|}
\hline Statement & $\begin{array}{l}\text { Average score week } 1 \\
\qquad(\mathrm{n}=10)\end{array}$ & $\begin{array}{l}\text { Average score week } 6 \\
\qquad(\mathrm{n}=10)\end{array}$ & Positive change \\
\hline 1 & 3.6 & 3.7 & $\sqrt{ }$ \\
\hline 2 & 3.1 & 3.1 & \\
\hline 3 & 3.6 & 3.8 & $\sqrt{ }$ \\
\hline 4 & 3.6 & 3.6 & \\
\hline 5 & 3.5 & 3.8 & $\sqrt{ }$ \\
\hline 6 & 3.1 & 3.1 & \\
\hline 7 & 3.2 & 3.2 & \\
\hline 8 & 3.5 & 3.9 & $\sqrt{ }$ \\
\hline 9 & 3.4 & 3.4 & \\
\hline 10 & 4.0 & 4.0 & \\
\hline 11 & 3.6 & 3.9 & $\sqrt{ }$ \\
\hline Total & 3.47 & 3.60 & $\sqrt{ }$ \\
\hline
\end{tabular}


Table 5. Number of students who have naïve or informed views of NOS aspects in week 1 and week 6

\begin{tabular}{lcccc}
\hline NOS aspect (Question) & \multicolumn{2}{c}{ Week 1 } & \multicolumn{2}{c|}{ Week 6 } \\
\cline { 2 - 5 } & Naïve & Informed & Naïve & Informed \\
\hline Requirement experiments (2) & 10 & - & 3 & 7 \\
Change in theory (3) & 10 & - & 6 & 4 \\
Difference theory and law (4) & 10 & - & - & 10 \\
Creativity and imagination (5) & 10 & - & - & 10 \\
Model (6) & 10 & - & & \\
\hline
\end{tabular}

